\title{
LEILA DANZIGER
}

「」

Micha Ullman: escavar, revolver, lembrar

RESUMO

O ensaio apresenta a obra do artista israelense Micha Ullman. Seu apego ao solo ganha forma em escavações que afirmam a nova realidade das práticas (anti)monumentais a partir da segunda metade do século $X X$, que conduzem nosso olhar a um movimento descendente, levando-nos a tomar consciência das complexas relações entre subterrâneo e superfície, memória e esquecimento.A obra de Ullman confere forma à memória traumática, que dificilmente se integra à vida, e faz surgir inscrições, grutas, criptas escavadas no espaço urbano e na história. Ullman ativa um novo eixo de operações artísticas - a partir do Oriente Médio -, criando relações tensas e necessárias com o Ocidente. No texto, são feitas aproximações entre Ullman e Hélio Oiticica, assim como à poesia de Paul Celan.

PALAVRAS-CHAVE

Arte contemporânea; terra; monumento; memória. 


\section{MICHA ULLMAN: ESCAVAR, REVOLVER, LEMBRAR}

Em 1932, o escritor austríaco Robert Musil observava, com humor e ironia, que não havia nada mais invisível do que os monumentos públicos. Referia-se aos monumentos tradicionais, produzidos pela cultura histórica do século XIX, tão criticada por Nietzsche em suas Considerações intempestivas sobre a história. Mas, já nas primeiras décadas do século $X X$, as vanguardas - direcionadas com vigor para o futuro - assimilavam com dificuldade a prática de obras públicas comemorativas. Sintomaticamente, um dos monumentos modernos mais célebres - o Monumento à III Internacional, de Tatlin - não chegou a ser construído, mas sua presença espectral (em fotografias e maquetes) teve a força de se fazer presente em obras como as de Dan Flavin e Claes Oldenburg, artista que compreendeu perfeitamente o destino do monumento moderno - seu percurso do heroísmo revolucionário ao esvaziamento.

Nas últimas três décadas, vimos surgir uma nova prática de obras públicas, que procuram instalar dispositivos espaço-temporais que não encubram a cidade com formas e monumentos tradicionais, e sim a desvelem, abram espaços, visadas, horizontes, propiciem mediações, passagens e limites (muitas vezes de modo temporário) ou, ainda inscrevam datas, nomes e senhas na cidade há tempos compreendida como um inesgotável texto. Nesse novo direcionamento das obras de arte em espaço público, inscreve-se a produção do israelense Micha Ullman, fundada em uma intensa experiência do solo - compreendido em suas dimensões geográficas, históricas e políticas - e tomado como espaço a ser efetivamente escavado, reconquistado por ações poéticas.

Desde o início de sua produção, nos anos 60, o artista interessa-se pelo conceito de natureza, tão problemático para a arte e para o pensamento ao longo dos séculos. Se, para Plínio, em sua Historia naturalis, a natureza é aquilo que se perde - uma herança perdida' -, para Ullman, a natureza é algo a ser conquistado (mas não simplesmente dominado pela técnica) e, sobretudo, compartilhado, em operações cercadas de aporias. Há quatro décadas o artista escava - literalmente - obras de arte pública que revolvem de modo crítico parte considerável da recente história ocidental. Em suas intervenções, atualiza-se a direção descendente da escultura moderna e do (anti)monumento contemporâneo, pois os gestos construtivos e perceptivos da obra conduzem para baixo, conectam-nos a algo subterrâneo e oculto. 
É a partir de uma prática da gravura, iniciada em Londres em 1965, que Ullman descobre o interesse por incisões profundas, verdadeiras escavações na matriz em metal, e a abertura de vazios, o que o conduz à escultura e a ações plásticas próximas às da Land Art. Mas, ao contrário de artistas americanos, tais como Michael Heizer e Robert Smithson, entre outros, que manobravam, com imensa desenvoltura, extensas camadas geológicas, imagéticas e discursivas (é certo que num mundo sempre assombrado pela catástrofe final), os gestos de Ullman enfrentam, desde o início, outra resistência, ao realizarem-se a partir de um território exíguo e incerto. "O campo agrícola e o campo de batalhas militares são parte de minha biografia", ${ }^{2}$ afirmou o artista, que cresceu num kibutz e, durante três décadas, foi soldado reservista do exército de Israel. Nascido em Tel Aviv, em 1939, de uma família de judeus alemães que fugia do nazismo, Ullman conta que seu “retorno" à língua alemã se fez lentamente. Apenas em 1972, em sua primeira visita à Alemanha, consegue falar alemão - idioma nunca totalmente abandonado pela família na intimidade - e experimenta intensa resistência à língua, que fala inicialmente como se tivesse "cascalho na garganta". ${ }^{3}$

Do interesse pela natureza como problema artístico, um de seus quatro elementos emerge como foco privilegiado, a terra. Sabemos que adamah - terra em hebraico - tem um valor simbólico decisivo na construção do Estado de Israel e que a palavra tem sua origem no nome próprio Adam. Percebemos, na obra de Ullman, a atualização dessa valorização da terra - em sentido literal e simbólico-, experimentada a partir de uma perspectiva rigorosamente contemporânea, que conecta distintas temporalidades, ao entrelaçar ressonâncias bíblicas a especificidades da história e da cultura judaica e israelense no século $X X$.

$A$ ação de escavar se faz presente na obra de vários artistas da década de 60 . No célebre Double negative (1969-70), Heizer escava duas inscrições gigantes no deserto de Nevada, deslocando 240 mil toneladas de rocha. As ações e as reflexões dessa geração de artistas americanos partem de um complexo embate com o circuito de arte - americano e internacional -, problematizando as categorias do tempo e do espaço, questionando o conceito de obra (e a falaciosa visão de pureza modernista), ao estabelecer relações entre o site e o não site, como tão bem definiu Robert Smithson. Esse artista está entre os que mais se dedicaram a pensar - e, efetivamente, a criar - ações que envolvem a terra, a ponto de relacionar de forma indissolúvel as transformações da terra e os processos mentais. "A mente e a terra encontram-se em um processo constante de erosão: rios mentais derrubam encostas abstratas, ondas cerebrais desgastam rochedos de pensamento (...)". ${ }^{4}$ Para o americano, as palavras possuem camadas de sedimentos:"olhe para qualquer palavra por bastante tempo e você vai vê-la se abrir em uma série de falhas, em um terreno de partículas, cada uma contendo seu próprio vazio". ${ }^{5}$

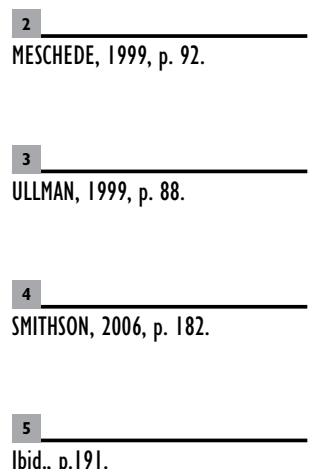

Ibid., p.|91. 


\section{Metzer-Messer e devolver a terra à terra}

Se as ações artísticas de Micha Ullman assemelham-se àquelas da Land Art, é necessário lembrar que encontram dificuldades muito distintas daquelas enfrentados por seus colegas americanos. Em 1972, cinco anos após tomar parte na Guerra do Sinai, Ullman realizou uma intervenção que consistia em uma troca de terra, o elemento mais disputado da região. $O$ artista escavou um buraco no kibutz de Metzer e outro na pequena cidade palestina de Messer. Em seguida, o buraco do kibutz foi preenchido com terra palestina e o buraco escavado em Messer recebeu terra israelense (Fig. I).

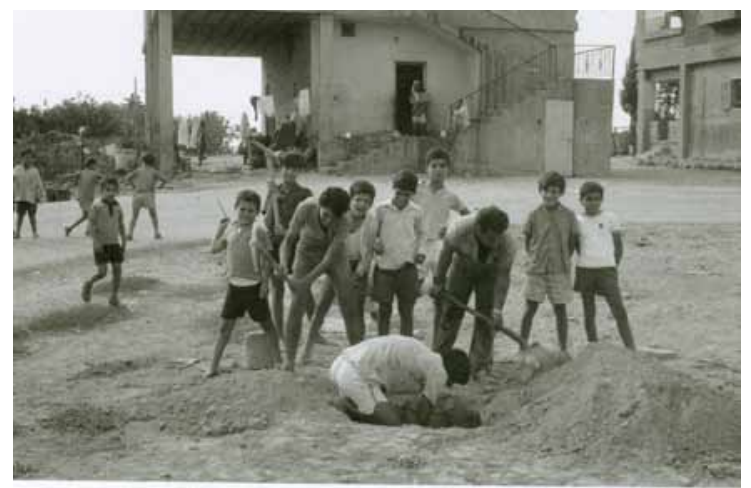

O kibutz, fundado em 1953, por judeus argentinos, situa-se próximo à fronteira da Cisjordânia e, desde o início de sua fundação, procurou estabelecer relações de convivência solidária com a comunidade árabe que lhe é vizinha. Apesar das enormes diferenças e incríveis tensões ao longo de seis décadas, os dois lados parecem compreender que as adversidades também os unem.As escavações de Ullman parecem dar forma a essa micropolítica estabelecida pelos habitantes daquela região, ${ }^{6}$ cuja convivência pacífica e solidária foi abalada - mas não destruída pelo atentado ocorrido em 10 de novembro de

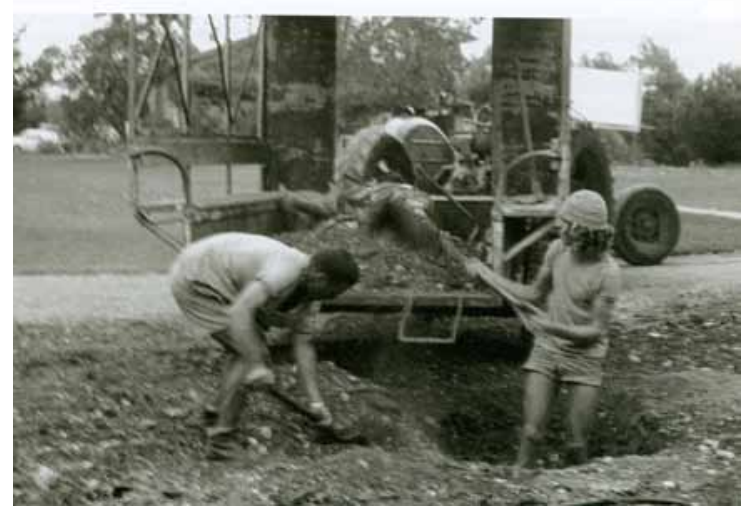

Fig. I

6

Disponivel em: <http://www.metzer. org.il/dukium/index.htm>.Acesso em: 28 jul. 2010.

7

BLOCH, 2005, p.I5. 2002, quando cinco moradores do kibutz foram assassinados em suas casas durante a noite.

Da troca de terra promovida por Ullman em 1972, restam apenas algumas fotografias, em que vemos os buracos sendo escavados, cada qual em seu terreno, com a ajuda de simples pás, e a terra, aos poucos, sendo depositada em um pequeno caminhão. Nada é plantado ou enterrado. $O$ vigor dos gestos destina-se a uma ação que o artista sabe ser efêmera e talvez vã. Ou não. Pois a obra aposta na espera, ou melhor, na utopia, como afirmou Ernst Bloch, "a esperança sabedora e concreta" que irrompe subjetivamente contra o medo de uma espera passiva. ${ }^{7} A$ ação não tem nenhuma outra finalidade senão estabelecer relações, fazer com que cada território acolha o outro lado, a outra terra, que, com sua composição específica, materializa o desejo de alteridade. Uma diferença na coloração das superfícies dos buracos já fechados, registrada nas fotos, é o único vestígio que, ao fim e ao cabo, restaria dessa operação. 
Suas dimensões singelas, a escala tão humana e a orientação explicitamente conceitual e política do trabalho fazem pensar no Bólide, ou melhor, no Contrabólide Devolver a terra à terra, de Hélio Oiticica, realizada em dezembro de 1979, na região do Caju, no Rio de Janeiro (Fig. 2).

De modo distinto ao de Micha Ullman, que se sente próximo às intervenções da Land Art, Oiticica afirma que sua ação na terra nada tem a ver com as intervenções dos americanos ${ }^{8}$, compreendendo-a a partir das relações entre a cor-pigmento e a terra, dando continuidade à lógica que fez surgir os Bólides.

No Caju, bairro célebre pela presença de um cemitério e pela proximidade com a zona portuária, o artista escolheu um terreno que servia como depósito de lixo para realizar o enterro do Bólide, como objeto, e seu renascimento como um ato. ${ }^{9}$ Sabemos que, para Oiticica, o Bólide é um transobjeto, em que o artista opera pela súbita identificação de uma concepção subjetiva com um objeto já existente. ${ }^{10} \mathrm{O}$ Bólide-caixa não é um mero recipiente para guardar o que quer que seja (pigmento, terra etc.), mas sim um projeto de dar concreção a estes materiais.

No Contrabólide Devolver a terra à terra - também intitulado Kleemania, em homenagem ao centenário de Paul Klee -, o artista desenvolve a contraoperação poética que gerou o conceito de Bólide. Ele preenche uma fôrma vazada de madeira $(80 \times 80 \times 10 \mathrm{~cm}) \mathrm{com}$ terra, que não é recolhida na região do bairro do Caju, mas trazida de outro lugar:
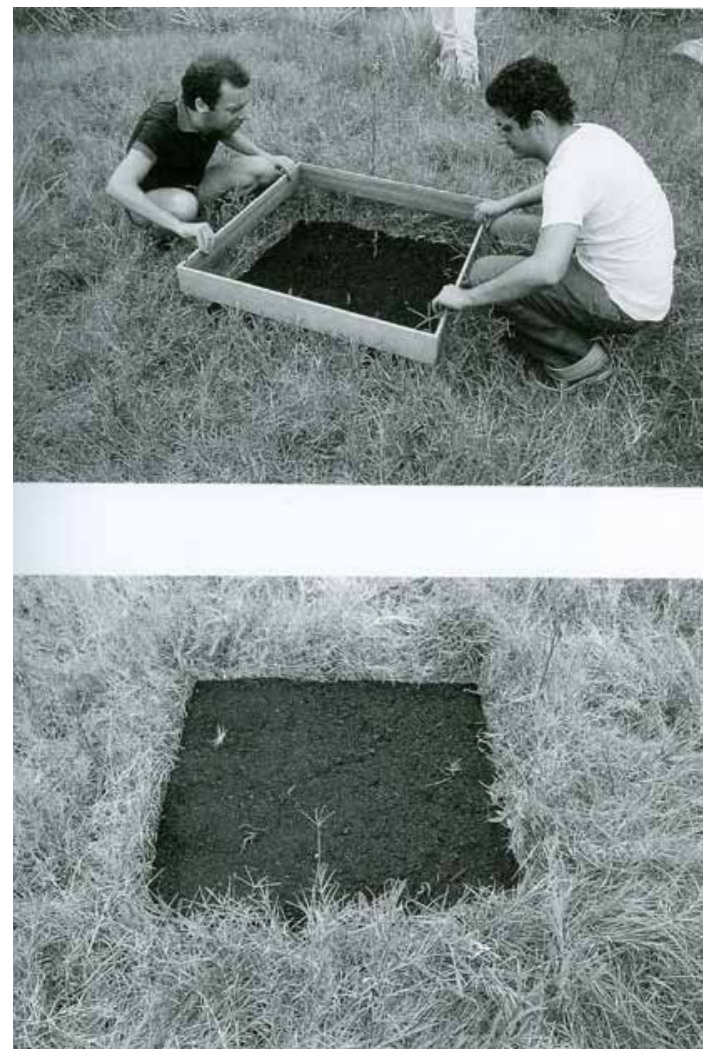

Fig. 2

\section{[...] em vez de ser esta terra colocada num container é ela colocada nessa cerca sem fundo: o fundo é a própria terra da localidade onde foi colocada a forma: a forma é então retirada deixando entãoTERRA SOBRETERRA q fica ali: o CONTRA-BÓLIDE passa a ser então em vez de obra uma espécie de programa-obra in progress que pode ser repetido quando houver ocasião-necessidade para tal (...)"."}

Ao término da ação, a terra depositada sobre o mato desenha um perfeito quadrado negro, uma das formas mais emblemáticas da pintura abstrata no século $\mathrm{XX}$, atualizada no espaço do mundo ou, mais precisamente, incorporada ao espaço

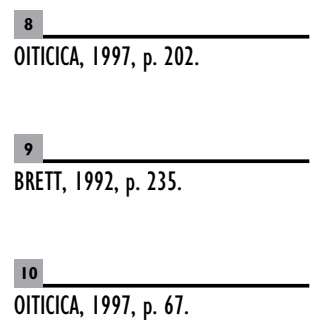

11 OITICICA, 1997, p. 67. Foram respeitados os grifos e a ortografia do artista, presente em seus escritos. 
12

Disponivel em: <http://www.itaucultural.org.br/aplicexternas/enciclopedia/ho/detalhe/docs/dsp_imagem.cfm?name $=$ Normal $/ 0052.79$ - 68.gif>. Acesso em: 24 de abr. 2009.

13

OITICICA, 1992, p. 202.

14

0z, 2004, p. 46. do mundo. O teor explicitamente político desta "pintura" rebaixada (no sentido do "informe" de Bataille") parece carregar assim as aspirações utópicas da modernidade - seu desejo de dissolver a arte na práxis vital.

No momento em que Oiticica realizava essa ação, o Brasil vivia o final da ditadura, o início da abertura política que faria a passagem para a democracia. Um dos tantos sentidos da obra pode ser dado a partir da carta de Antônio Manuel, enviada da Antuérpia, em que o artista e amigo de Oiticica lamentava a impossibilidade de participar "de corpo presente" da ação no Caju e ressaltava o caráter eminentemente explosivo - em sentido literal e simbólico - daquele solo e região, próxima do antigo complexo do Gasômetro de São Cristóvão, hoje desativado, e que durante a década de 70 era assombrado pela ameaça de voar pelos ares em algum atentado. "Atenção como vão mexer nas terras do caju. Cuidado, do contrário elas podem explodir, pois caju é energia latente - seus gases estão no ar."12

Interessante observar que Oiticica considera a carta enviada por Antônio Manuel como extensão de Kleemania, expandindo assim, incrivelmente, o campo de ação poética de seu Contrabólide, estabelecendo relações entre o distante porto da Antuérpia e o porto do Rio de Janeiro. "Eu aqui do Oceano Atlântico estico meu corpo até as pontas do Caju e respiro suavemente seus gazes”, escrevia Antonio Manuel em 9 de janeiro de 1980.

A experiência de Devolver a terra à terra foi repetida após a morte do artista, ao longo dos anos de 1992 e 94, durante mostra itinerante de suas obras pela Europa e pelos Estados Unidos. Cumpria-se assim o destino daquela ação poética de atualizar-se como "programa-obra in progress", que poderia se repetir sempre que necessário. ${ }^{13}$

Creio que a intervenção Messer-Metzer, de Ullman, possui vocação semelhante, desejando propagar-se e repetir-se de forma crítica, sempre atenta à singularidade de cada situação, ativando - na especificidade da prática artística - situações políticas e sociais específicas, ou seja, construindo dissensos produtivos. A ação de Ullman é voltada para a questão da alteridade e do convívio, ao lidar com a partilha da terra, experiência que une israelenses e palestinos em uma tragédia que ainda não teve fim. Compreenda-se a palavra tragédia em seu sentido mais exato, como tão bem definiu Amós Oz, em Contra o fanatismo:

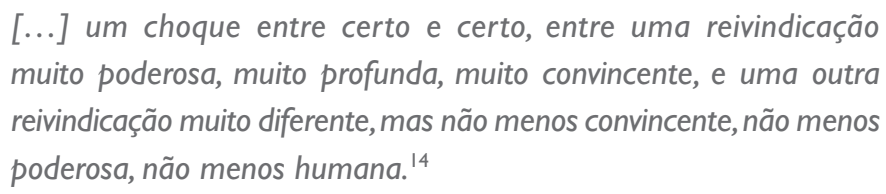

[...] um choque entre certo e certo, entre uma reivindicação muito poderosa, muito profunda, muito convincente, e uma outra poderosa, não menos humana. ${ }^{14}$ 


\section{Terra e corpo}

Muitas esculturas de Ullman são feitas de areia avermelhada, característica da região próxima de onde vive o artista, ao norte de Tel Aviv. Em 1975, ele realizou o filme Place, em que transforma continuamente certa quantidade de areia em configurações efêmeras. $O$ volume de terra usado no trabalho iguala o volume do corpo do artista, que foi medido precisamente pelo número de baldes de água que devem ser retirados de uma banheira cheia para que ele pudesse nela imergir. Assim, o artista estabelece uma íntima relação entre seu corpo e a areia.

Ao observarmos suas esculturas, percebemos que elas jamais perdem de vista a escala humana, construindo uma espacialidade cuja referência são sempre o corpo e a casa, mesmo que esta esteja sempre esvaziada. A casa, na obra de Ullman, apresenta-se como local de desamparo, pois deveria servir de abrigo, mas não cumpre essa função.

Na obra Grund, apresentada na Documenta 8 (Kassel, 1987), Ullman escavou uma cratera, que sugere a marca em negativo deixada por um telhado (como se a casa viesse a ser construída com o telhado fincado na terra e as fundações voltadas para o céu). A partir das margens, sobre o declive construído, duas grandes toras de ferro projetam-se como plataformas sobre o fosso. Ao final de uma delas, há um corte na forma de uma cadeira invertida, que nos convida a ocupá-la em imaginação. Ullman produz assim uma inversão do espaço da casa. A simplicidade da forma da cadeira é, para Ullman, o lugar simbólico do ser humano entre terra e céu. $O$ título Grund pode ser traduzido como fundo, solo, terreno, terra, base ou fundamento, e dá origem ao verbo "grunden”, que significa, em alemão, fundar, estabelecer, instituir. Podemos compreender as escavações de Micha Ullman como a tentativa renovada de fundar e habitar ausências.

A forma da casa aparece claramente nas obras que se intitulam Dia, Havdahah e Noite, feitas em grandes dimensões e instaladas em espaço público, ou também em dimensões mais reduzidas, todas elas misturando ferro e areia, lidando com o cheio e o vazio, o dentro e o fora ou, ainda, a necessidade de proteção e sua impossibilidade. Mostradas em conjunto, numa série inseparável, as esculturas se referem à passagem do tempo e à forma de acolher a luz e as sombras.

Havdalah é a cerimônia realizada ao fim do Shabat (o sétimo dia da semana, santificado no judaísmo), para marcar a passagem do tempo sagrado ao tempo prosaico da vida cotidiana. Talvez uma possível leitura da obra de Ullman seja feita a partir de um poema em que Paul Celan se refere a essa cerimônia.Vale lembrar que, para Adorno, a poesia de Celan responde de modo legítimo - ou seja, na infinita discrição - ao horror extremo. "A infinita discrição com que procede o radicalismo de Celan aumenta a sua força. A linguagem inanimada torna-se a última consolação da morte privada de todo o sentido." 15 


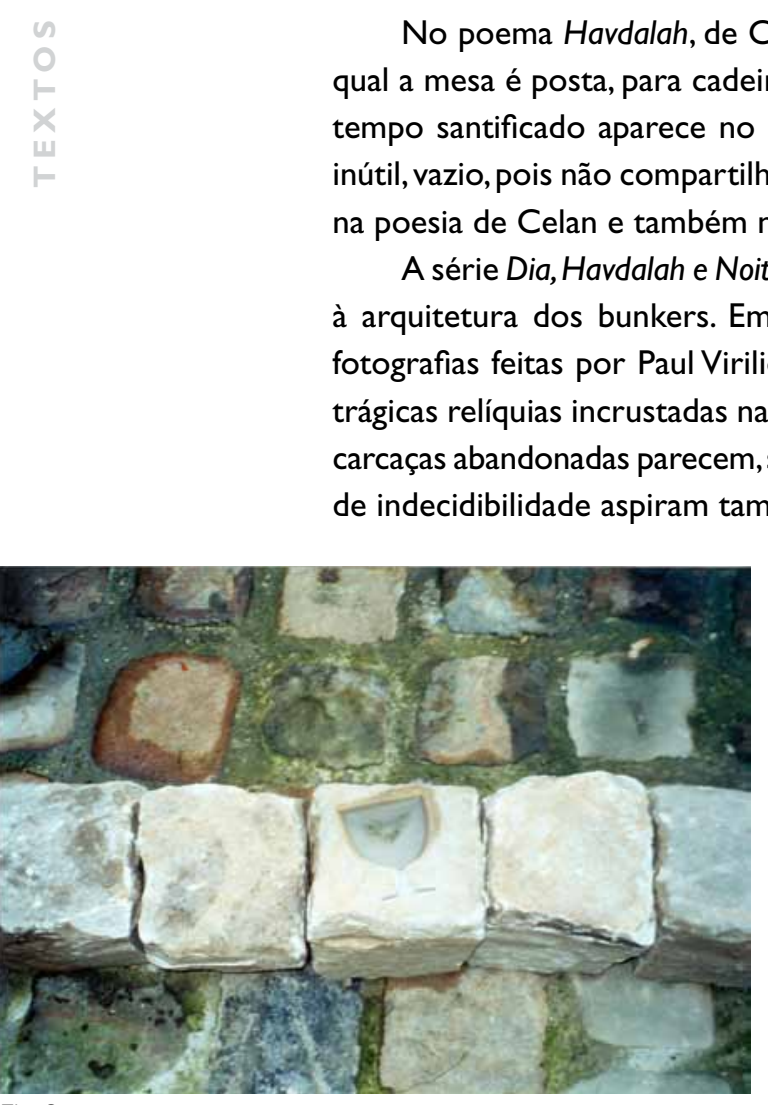

Fig. 3

16

CELAN, 1968, p. 90.

17

CELAN, 1999, p. 40-41. década de 1990. Interessante notar que as formas côncavas incrustadas nas pedras podiam se tornar momentaneamente plenas quando repletas de água da chuva (Fig. 3). Materializa-se, assim, a ideia de uma cerimônia em que se compartilha a plenitude de ausências. Mais uma vez, a poesia de Celan:"Nas longas mesas do tempo/ embebedam-se os cântaros de Deus. [...] levam à boca o vazio como o pleno/ e não transbordam como eu ou tu". ${ }^{17}$

Mesmo que na forma de uma ficção, a instalação Conversation evoca os princípios gerais da mnemônica clássica, que relaciona loci e imagines (lugares e imagens). Em $A$ arte da memória, Frances Yates retoma uma história contada por Cícero, em que o poeta Simônides de Ceos se retira de um banquete pouco antes do desabamento do teto do edifício onde a festa se realizava. Sob os escombros, a deformidade dos corpos impedia seu reconhecimento."Mas Simônides recordava-se dos lugares dos convidados à mesa e assim pôde indicar aos parentes quais eram seus mortos" (...). 


\begin{abstract}
Ele inferiu que pessoas que desejavam treinar essa faculdade (da memória) precisam relacionar lugares e formar imagens mentais das coisas que querem lembrar, e guardar essas imagens nesses lugares, de modo que a ordem dos lugares preserve a ordem das coisas, e as imagens das coisas denotem as próprias coisas; e devemos empregar os lugares e as imagens assim como uma tábua de cera sobre a qual são inscritas letras. ${ }^{18}$
\end{abstract}

\section{Memória topográfica}

Várias obras de Ullman partem dessa consciência de que a memória precisa se inscrever em lugares, mesmo que pela natureza da memória traumática dos eventos a serem lembrados, não seja a plenitude da memória que se faça presente, mas tãosomente cacos, estilhaços, fragmentos e o imperativo de uma tarefa infinita, pois o trabalho da memória é algo sempre a recomeçar.

Nessa exposição do Museu de Arte e História do Judaísmo, em Paris, as pedras transportavam a topografia do subterrâneo para a superfície; em obra realizada em Lodz (Wschodnia, 1990), o que está em jogo também é a memória topográfica. Um diagrama é construído sobre o asfalto, sugerindo uma casa demolida, da qual restariam apenas as marcas das paredes, as silhuetas de duas cadeiras e de uma mesa. Este desenho no solo é situado próximo ao antigo gueto judaico da cidade e sugere um único e exíguo cômodo, estranhamente deslocado para o centro da rua. As marcas lembram aquelas deixadas pelas barracas destruídas nos campos de Sachsenhausen e Dachau, por exemplo. A sugestão da casa demolida no lugar de passagem dos carros é bastante singular, sugerindo o caráter incontornável do trabalho de memória, colocado literalmente no "meio do caminho", sem desvios possíveis. Sutil e potente, o diagrama inscrito no solo significa prontamente exclusão e destruição. Creio que a vocação dessa marca no asfalto de Lodz é se propagar. Como tantos logos e marcas empresariais dispersas nas metrópoles, sua função é eminentemente comunicativa, embora sua carga seja erosiva, negativa, desoladora.

\section{Biblioteca}

A mais conhecida obra pública de Micha Ullman foi realizada em Berlim, um dos mais notáveis (anti)monumentos da cidade.Trata-se da Biblioteca (Bibliothek, 1994/95), situada na Bebelplatz. A obra destina-se a lembrar que, na noite de 10 de maio de 1933, ali foram queimados vinte mil livros de autores de língua alemã considerados decadentes e contrários ao verdadeiro espírito da cultura germânica. Robert Musil, Thomas Mann, Herbert Marcuse, Anna Seghers, Erich Maria Remarque foram alguns

18 CÍCERO apud YATES, 2007, p. 18. 
dos escritores nomeados individualmente, antes de terem suas obras lançadas às chamas: "Contra a decadência e a ruína moral! Pela raça e pelos costumes na família e no Estado! Eu entrego às chamas Heinrich Mann, Ernst Gläser, Erich Kästner...". 19

Na praça um pouco retirada no grande eixo da Unter den Linden, um dos centros históricos mais importantes da cidade, inexistem elementos verticais, bancos ou vegetação. Não fosse um permanente grupo de pessoas no centro da extensa grade horizontal formada pelo calçamento de pedras, a existência do monumento passaria despercebida. A obra se constitui num espaço
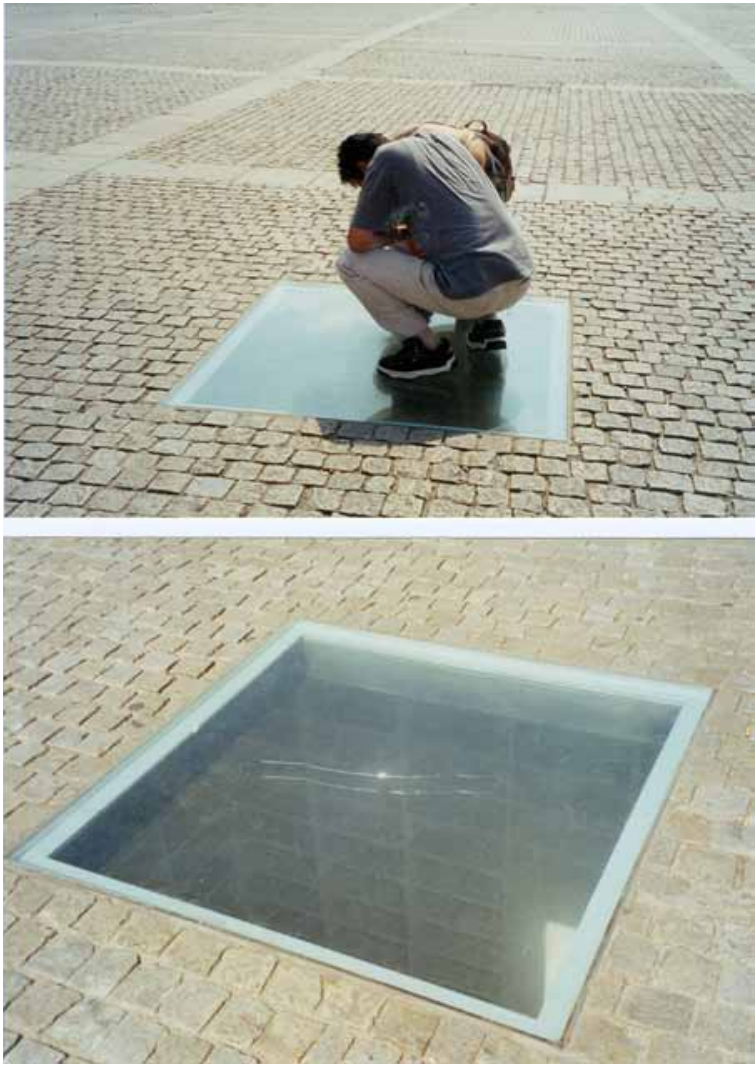

Fig. 4

A biblioteca subterrânea poderia conter, em suas estantes vazias, cerca de vinte mil livros - número de exemplares que se estima terem sido queimados naquele lugar. O monumento escapa à tentação de reproduzir a grandiloquência e a teatralidade do ato público da queima de livros e concebe a monumentalidade de modo introvertido e concentrado. Como em outras obras de Ullman, as dimensões do monumento foram pensadas em relação ao corpo humano, pois derivam de quatro vezes a estatura

19

MESCHEDE, 1999, p. II. cúbico subterrâneo de 7,06 metros de aresta. Não há ponto de vista que permita ao olhar uma visão total do recinto embutido no solo. A visada da obra impõe curiosa movimentação: o observador é levado a recuar e a avançar, a curvar-se, abaixar-se, a mudar continuamente de posição, no intuito de apreender o espaço subterrâneo. $O$ olhar duvida; há surpresa, incredulidade e frustração. Estantes vazias recobrem as paredes de modo ambíguo, ora parecendo recuar como crateras, ora avançando. Biblioteca refere-se assim ao auto de fé nazista, no próprio local de seu acontecimento; opera, assim, com um índice de realidade histórica e atualiza, de modo crítico, o gesto destruidor dos estudantes alinhados ao partido nazista (Fig. 4).

Duas placas instaladas no solo, a alguns metros da obra, fazem referência ao fato.À direita podemos ler:"No meio desta praça, em 10 de maio de 1933 , estudantes nacional-socialistas queimaram centenas de obras de escritores, jornalistas, filósofos e cientistas"; enquanto a placa da esquerda traz uma frase premonitória de Heinrich Heine, que em 1820 escrevia:"Isso foi um prelúdio. Lá, onde se queimam livros, queimam-se por fim também seres humanos". média de uma pessoa ( $1,75 \mathrm{~m})$. De noite, a biblioteca subterrânea torna-se um cubo 
de luz com potência de 1.750 watts e deixa que seus limites sejam apreendidos de modo mais nítido, transformando-se realmente num abismo. Cabe aqui, mais uma vez, a lembrança da poesia de Celan, uma das passagem de Meridiano, em que Celan evoca Lenz, de Büchner: “... é que as vezes lhe era incômodo não poder andar de cabeça para baixo. Quem anda de cabeça para baixo, senhoras e senhores, quem anda de cabeça para baixo tem o céu como abismo."20

Devido a condições geológicas de Berlim, Biblioteca é uma construção complexa, que exigiu isolamento do curso d'água e um aparato que impedisse o embaçamento de seu tampo de vidro pela umidade. $O$ arquiteto Andreas Zerr, que trabalhou com Ullman, descreve o cubo subterrâneo da Bebelplatz como um pequeno barco, permitindo associações entre a biblioteca e uma arca, figura com ressonâncias bíblicas e redentoras. Seu tampo de vidro espesso exibe constantemente rachaduras, marcas, não da grande visitação, mas, principalmente, da incompreensão e do vandalismo (em agosto de 2000, já havia sido trocado duas vezes). Além de isolar a "biblioteca" e permitir que o observador se posicione sobre o "abismo" - integrando-se assim ao monumento -, a função do tampo de vidro é refletir e atrair, para o campo de gravidade da obra, a imagem do impressionante entorno arquitetônico do século XVIII, situado na Bebelplatz.

$\mathrm{Na}$ entrada da praça - conhecida entre 1910 e 1947 como Kaiser-Franz-JosephPlatz -, está a Deutsche Oper Unter den Linden, arquitetura de Knobellsdorf, maior Ópera da Europa na época de sua construção, em meados do século XVIII. Ao fundo da praça, destaca-se a grande cúpula da Catedral Santa Hedwig, projetada também por Knobellsdorf, sinal da tolerância de Friedrich II com os católicos. A menção à catedral, reconstruída em 1952-63, solicita pequena digressão pelo nome do arcebispo católico Berhard Lichtenberg. Como lembra Hanna Arendt, "ele não só ousou rezar em público por todos os judeus batizados ou não (...), como também solicitou autorização para se juntar aos judeus em sua viagem para o Leste. Morreu a caminho do campo de concentração". ${ }^{21}$

Mas a construção que domina a praça é a antiga Biblioteca Real, chamada pelos berlinenses de "Cômoda", pois sua forma extensa e arredondada lembraria um móvel barroco. As imagens refletidas destes dois edifícios - a Biblioteca Real (atualmente Universidade Humboldt) e a catedral - misturam-se ao reflexo do céu, das nuvens, do próprio observador empenhado na tentativa de olhar e compreender a obra."As pessoas que entram na praça são incluídas no monumento. A Biblioteca de Micha Ullman deve ser vista sempre nessa dialética entre a forma subterrânea e o observador na superfície", afirma Friedrich Meschede. ${ }^{22}$

Biblioteca faz parte de uma rede de monumentos que inscreve, criticamente, a memória dos crimes do nacional-socialismo na capital de uma Alemanha reunificada e normalizada. Desde a queda do muro, Berlim demonstrou extraordinária capacidade de

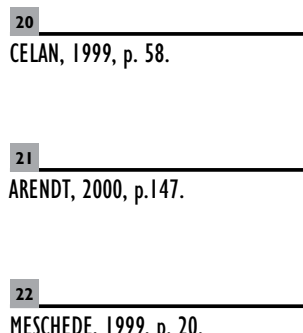

MESCHEDE, 1999, p. 20. 
cicatrização. Obras como La maison manquante ( 199 I), de Christian Boltaski, Lugares da memória (1993), de Renate Stih e Frieder Schnock, e Plataforma 17 (1997), de Hisrch, Lorsch e Wandel, entre várias outras, sinalizam a supressão abrupta e insanável dos judeus na cidade. Com intensidades distintas, tais intervenções permitem perscrutar os caminhos da violência consumada, inscrevendo camadas de história, memória e sentido na nova república berlinense. Como tão bem disse Andreas Huyssen:"Talvez não haja outra grande cidade ocidental que suporte as marcas da história do século XX tão intensamente e de forma tão autoconsciente como Berlim". ${ }^{23}$

\section{REFERÊNCIAS}

ABRAMSON, Glenda. Encyclopedia of modern jewish culture. New York: Routledge, 2005.

ADORNO,Theodor. Teoria estética. Lisboa: Ed. 70, 1970.

ARENDT, Hanna. Eichmann em Jerusalém: um relato sobre a banalidade do mal. São Paulo: Companhia das Letras, 2000.

BLOCH, Ernst. O princípio esperança. Rio de Janeiro: Editora da UERJ, 2006.

BRAGA, Paula. A trama da terra que treme: multiplicidade em Hélio Oiticica. 2007. Tese. (Doutorado) Programa de Pós-graduação em Filosofia, Letras e Ciências Humanas, Universidade de São Paulo, São Paulo. Disponível em: <http://www.fflch.usp.br/df/site/posgraduacao/2007_doc/2007_doc_paula_braga209pg. pdf>.Acesso em: 28 jul. 2010.

Carta de Antônio Manuel - Projeto Hélio Oiticica, Itaú Cultural

Disponível em: <http://www.itaucultural.org.br/aplicexternas/enciclopedia/ho/detalhe/docs/dsp_imagem. cfm?name=Normal/0052.79 - 68.gif>.Acesso em: 28 jul. 2010.

CELAN, Paul. Ausgewählte Gedichte. Frankfurt: Suhrkamp, 1968.

CELAN, Paul. Conversa na montanha. Tradução de Vera Lins. Inimigo Rumor, Revista de Poesia, Rio de Janeiro: 7 Letras, n. 8, 2000, p. 66-68.

CELAN, Paul. Cristal. Tradução de Cláudia Cavalcanti. São Paulo: lluminuras, 1999.

Coexistência pacifica. Disponível em:<http://www.metzer.org.il/dukium/index.htm>.Acesso em:28 jul. 2010. http://www.bbc.co.uk/portuguese/noticias/2002/02 I I I I_guilamtc.shtml Acesso em: 28 jul. 2010.

DANZIGER, Leila. Corpos de ausências: Berlim e os monumentos a Auschwitz. 2003. Tese. (Doutorado em História) - Departamento de História, PUC, Rio de Janeiro. Disponível em: <http://www2.dbd.puc-rio. br/pergamum/biblioteca/php/mostrateses.php?open=I\&arqtese=98/5228_03_Indice.htm/>. Acesso em: 28 jul. 2010.

HUYSSEN,Andréas. Seduzidos pela memória. Rio de Janeiro:Aeroplano, 2000.

23

HUYSSEN, 2000, p. III.
MESCHEDE, Friedrich. Bibliothek - von Micha Ullman. Amsterdam; Dresden:Verlag der Kunst, 1999.

MOSĖS, Stephane. Quand le langage se fait voix. Paris: Michel Chandeigne, 1990. 
OITICICA, Hélio. Catálogo do Projeto Hélio Oiticica. Paris: Galerie du Jeu de Paume; Rio de Janeiro:Projeto H.O.I Instiuto Municipal de Cultura RioArte, 1997.

OZ,Amós. Contra o fanatismo. São Paulo: Companhia das Letras, 2005.

ROSSET, Clement. L'Anti-nature. Paris: Presses Univesitaires de France, 1973.

ULLMAN, Micha. Conversation: exposição: I5 de novembro de 2000 a 5 de março de 200I. Musée d'art et d'histoire du Judaïsme, Paris. Folder da exposição.

ULLMAN, Micha; Stephen, A. Verschlossene Räume: Micha Ullmanns Denkmalsentwurf für den Berliner August-Bebel-Platz. Ein Gespräch mit Angelika Stephen, Neue Bildende Kunst, Forum, n I, 1994, p. 86-89. YATES, Frances. A arte da memória. Campinas: Ed. da Unicamp, 2008.

\section{$\Gamma$}

\section{LEILA DANZIGER}

Artista plástica e professora dos cursos de graduação e pós-graduação do Instituto de Artes da UERJ. Graduou-se em Artes, pelo Institut d'Arts Visuels, Orléans, França. Concluiu doutorado em História Social da Cultura, pela PUCRio, com estágio na Universidade de Oldenburg, Alemanha (bolsa Capes/PDEE). Trabalha com os seguintes temas: articulações entre arte, história, memória e esquecimento; imagem e escritura; arte e mídia. É Jovem Cientista do Nosso Estado, pela Fundação de Amparo à Pesquisa no Estado do Rio de Janeiro (FAPERJ), na área de artes plásticas. 